\title{
STRENGTHENING CRITICAL THINKING SKILLS AMONG MUSLIM STUDENTS
}

\author{
Abdul Karim Abdullah (Leslie Terebessy)*
}

\begin{abstract}
The intention of this article is to reflect on how critical thinking among Muslim students could be enhanced. After a survey of key qur'ānic verses related to thinking, a review of literature follows. Thinking and critical thinking, as well as their relationship to one another are explored next. Various activities in which critical thinking plays a key role are highlighted. Reasons for the weakness in critical thinking are examined in the following section. The conclusion contains recommendations for the improvement of critical thinking skills among Muslim students.
\end{abstract}

\section{Introduction}

Commentators have noted a deficiency of critical thinking skills among graduates of Islamic institutions of learning. In the words of one of them, "our traditional system, for all its virtues, is sharply criticised [...] as lacking in [...] critical ability and for relying on rote learning and parrot fashion repetitions". ${ }^{1}$ Because of the overemphasis on memorisation at the expense of comprehension, some Muslim parents - who can afford it - enrol their children in non-Muslim educational institutions that employ more imaginative and critical approaches in learning activities. Islam, however, has resources for designing and delivering a complete education, including the development of critical thinking skills.

The mind or intellect ('aql) is part of what the Qur'ān identifies as the 'heart' (qalb or $f u^{\prime} \bar{a} d$ ). The 'heart' is the faculty of perception. The comprehension of revealed knowledge takes place by means of the 'heart'. In addition to the intellect (' $a q l$ ), the 'heart' includes intuition (ilhäm). ${ }^{2}$ Like the faculties of hearing and seeing, the 'heart' is a gift from God Most High.

It is He who has created for you (the faculties of) hearing, sight, feeling, and understanding: little thanks it is ye give! $!^{3}$

Allah placed many signs on the earth and in the heavens for His servants so they may reflect and receive divine guidance. These include the creation:

* Abdul Karim Abdullah (Leslie Terebessy) is Assistant Research Fellow at IAIS Malaysia. 
Behold! In the creation of the heavens and the earth, and the alternation of Night and Day - there are indeed signs for men of understanding -4

Humanity is asked to ponder upon the Qur'ān in order to receive admonition:

We have revealed for you (O men!) a book in which is a Message for you: Will ye not then understand ${ }^{5}$

The Qur'ān itself contains many signs ( $\bar{a} y \bar{a} t)$ of Allah:

(Here is) a Book which We have sent down unto thee, full of blessings, that they may meditate on its signs, and that men of understanding may receive admonition. ${ }^{6}$

The Qur'ān advises Muslims to open our hearts (and minds) to obtain knowledge of the Qur'ān and of the wonders of creation.

Do they not then earnestly seek to understand the Qur'ān, or are their hearts locked up by them? ${ }^{7}$

Islam is a "religion of reason". ${ }^{8}$ There is nothing in the Qur'ān that is "contrary to reason". ${ }^{9}$ Islam "is not based on mystic dogmatism but is always open to the critical inquiry of reason". ${ }^{10}$ The Qur'ān encourages us to use "our powers of reasoning [...] to the best of our ability and knowledge". ${ }^{11}$ It frequently uses expressions such as: "those who exercise their intellect" (ya 'qilün), "those who think" (yatafakkarün), "those who know" (ya lamūn), "those who ponder" (yatadabbarūn) and "those who understand" (yafqahūn). ${ }^{12}$ The Qur'ān censures people who do not think:

For the worst of beasts in the sight of Allah are the deaf and the dumb, - those who understand not. ${ }^{13}$

The Qur'ān is "the book that makes things clear" (al-kitāb al-mubīn) and the book "in which there is no doubt" (la raybah fihi). ${ }^{14}$ It is a book for all to study to the best of his or her ability. The Qur'ān teaches the difference between truth and falsehood: "The truth stands out clearly from error."15 The Qur'ān establishes the difference between truth and falsehood by responding to the claims of the disbelievers. It exhorts one to employ 'better' reasoning:

Call unto the way of thy Lord with wisdom and fair exhortation, and reason with them in the better way. Lo! thy Lord is Best Aware of him who strayeth from His way, and He is Best Aware of those who go aright. ${ }^{16}$

The Qur'ān exhorts everyone to open one's 'heart' (and mind) to the many signs of God: "the Qur'ān values rational endeavour accompanied by sincerity in the quest for truth and justice". ${ }^{17}$ Meaningful reading of the Qur'ān, however, requires its comprehension. Comprehension, in turn, requires the application of the intellect 
( $a q l$ ). In other words, it requires one to think. This should not be too difficult, as the Qur'ān refers to itself as "easy to understand and remember". ${ }^{18}$

\section{A Brief Review of Literature}

M. Hakan Yavuz, in his Islamic Political Identity in Turkey, ${ }^{19}$ comments on the Fethullah Gülen network of schools and universities throughout Turkey and other parts of the Muslim world:

Students in the Gülen movement's high schools in Turkey [...] still stress memorisation and conservative values more than critical thinking [...] the sense of duty or fulfilling one's mission is a more important virtue than being different or thinking critically. This lack of critical thinking is an outcome of a cultural and educational system that discourages questioning of social and religious values. Being the same as and being 'part of the group' and behaving in conformity with the group expectations are more important than carving a unique self. ${ }^{20}$

In "Islamic Education in Britain: Approaches to Religious Knowledge in a Pluralistic Society", ${ }^{21}$ Peter Mandaville reports that Zaki Badawi, the founder of the Muslim College in London, insisted on the "capacity for critical thinking as a prerequisite for entry into the college". ${ }^{22}$ Similarly, at the Markfield Institute of Higher Education, based on the thought of Abū 'l-A 'lā Mawdūdī (d. 1979), "students are encouraged to engage critically with the canon of Islamic thought, with an emphasis on identifying new areas of ijtihā $d " .{ }^{23}$ Yoginder Sikand, commenting on madrasah education in India, calls for "reform in teaching methods. Presently, the focus is simply on the learning, even memorising, of books, rather than actually understanding a discipline, as a result of which many students can hardly follow their lessons." ${ }^{24}$

In the Call for Heresy: Why Dissent is Vital to Islam and America ${ }^{25}$ Anouar Majid calls for 'heresy', as a way of advancing the case of critical thinking. He worries that fundamentalist forces are threatening both the US and the Muslim world. $\mathrm{He}$ fears the growing influence of 'puritanism' in his native Morocco, as well as in the wider Muslim world: "It is always a bit of a gamble to examine well-established traditions critically, for to question their foundations is akin, in some ways, to undoing the structure of our identities and communities. ${ }^{26}$ To raise sensitive topics from Islamic history "is to discover that the Muslim individual is governed [...] by a list of proscriptions (interdits) that stigmatizes critical thinking and frames the individual's life with carefully delineated norms." ${ }^{27}$ Majid calls on "both Muslims $[\ldots]$ and Americans [...] to embrace heretical thought, or freethinking, as the only life-saving measure left to avoid an apocalyptic future."${ }^{.28}$ 
Majid's fears of a global Islamic fundamentalist resurgence appear exaggerated. He simplistically - and altogether without justification - identifies critical thinking with heresy. He thus reinforces a popular stereotype of critical thinking among some Muslims, which is that critical thinking induces disbelief. He presumes, without demonstrating, that critical thinking necessarily undermines faith. On the contrary, thinking is required to comprehend and defend faith. One's intention in critical thinking is paramount.

A comparable view of critical thinking emerged at the conference, "A Celebration of Heresy: Critical Thinking for Islamic Reform”, held in 2008 in Atlanta, Georgia, United States. The conference "grew out of the recognition that often, dissenting ideas against the prevailing religious traditions are written off as heresy. Nearly all the prophets and great thinkers throughout history have been accused of being heretics." 29 Abdullahi An-Naim, Professor of Law at Emory University added: "This title emphasizes that we seek to promote our commitment to accept dissent and disagreement, because we believe that strong disagreement with the current views is a necessary pre-requisite for genuine and effective reform." He stated, "We celebrate heresy and dissent not as ends in themselves, but in order to enable and promote innovative and critical thinking." 30 Organiser, author, and activist Edip Yüksel added: "In the present atmosphere, one of the best places to hold such a conference is the United States, where Muslims can freely express their opinions without the fear of persecution." 31

A balanced assessment of critical thinking can be found in Khurshid Ahmad's "The Challenge of Global Capitalism: An Islamic Perspective", in John H. Dunning, Making Globalization Good: The Moral Challenges of Global Capitalism. ${ }^{32}$ The "Muslim world was a global economic power for several centuries, and it was not until the time of the Western Enlightenment that economic stagnation [...] began to occur: and this lasted for more than 300 years [...] a lot of critical thinking is taking place examining what originally went wrong and how the Muslim world can set its house back in order." 33 Khurshid Ahmad highlights the need for critical thinking in the regeneration of the Muslim ummah.

In 2007, the Institute of Strategic and International Studies (ISIS) in Kuala Lumpur, Malaysia - a think tank - held the International Forum on 'The Makkah Declaration: Implementing Economic Agenda of the Muslim World'. In his presentation, entitled "Education and Literacy in the Muslim World: Paths to the Future", Indonesian professor Azyumardi Azra observed: "It is unfortunate that in the teaching processes in Islamic education in general, rote learning tends to continuously dominate, not only in social sciences and humanities, but also in science teaching [....${ }^{934}$ Muslims still see knowledge as something to be memorised: "The attitude of mind is passive and receptive rather than creative and inquisitive [...] all knowledge comes to be viewed as unchangeable and all books tend to be memorised or even venerated." 
For this reason, "it is now necessary to introduce new methods of teaching in all levels of Islamic education $[\ldots]$ there are many subjects that need analytical and critical thinking [...]". ${ }^{35}$ Moreover,

The opposition of the Muslim orthodoxy to rational and empirical sciences, in the end created a seemingly unbridgeable gap between the so-called 'religious sciences' derived from the 'signs' of the Qur'ān (al-āyāt al-qur'āniyyah) on the one hand, and 'non-religious sciences' derived from the 'signs of being' (al-āyāt al-kawniyyah) on the other [...]. This dichotomy of sciences is undoubtedly also responsible for the backwardness of science and technology in the Muslim world. ${ }^{36}$

In Leadership Skills for Muslims, Dr Suriyakhatun Osman observes, "Critical thinking $[\ldots]$ is actually thinking as clearly as we can, avoiding faulty thinking $[\ldots]$. [It] is expected that a good Muslim thinks critically." ${ }^{37}$ Critical thinking includes interpretation, explanation and evaluation. The requirements of critical thinking include humility, freedom from bias, and questioning. Critical thinkers search for the truth, are analytical, self-confident, and inquisitive. "There will be things that we perceive to be true that turn out to be untrue [...]. Doctors could be misinformed, teachers could make mistakes. ${ }^{\prime 38}$ Bias can take many forms, including self-interest, cultural bias and personal bias.

Often we are not aware of the powerful effects that our culture has on us until we are exposed to other cultures or ways of thinking. Those people who have seen other people in other cultures will realise the effect of culture on thinking [...] we come from certain ethnic groups as well as subgroups like the village we were born in or grew up in that share common values and ways of doing things [...]. Critical thinkers are aware of these biases. ${ }^{39}$

Another important quality for critical thinking is intellectual courage. "This attribute of a critical thinker is the ability to think and voice thoughts that are unpopular. It is the capability to challenge beliefs that one holds dearly or that one's group or country accepts - often without question. It is the courage to question commonly accepted convictions or dogma in the face of ridicule or at the cost of great personal anguish. This is the Path of all the Prophets and the Reformers of Nations [...]." ${ }^{40}$

\section{Thinking and Critical Thinking}

Thinking is the activity of discovering, accumulating, and making use of knowledge. Reflection facilitates communication. It does so with the help of language, including sign language, which is generally easier to understand than the more complex verbal constructs characteristic of spoken and written language. Memory stores knowledge. Problem solving requires thinking but also the use of the imagination. 
Where thinking helps to identify, formulate and analyse problems, the imagination assists in solving them. Thinking presupposes questioning. With some exceptions, questioning is permitted in Islam. The expression, "They ask you (yas'alünaka)" occurs no fewer than 15 times in the Qur'ān. ${ }^{41}$ The answer invariably comes in the form of "Say (qul)". The Qur'ān puts a high premium on knowledge:

[...] Allah will raise up, to (suitable) ranks (and degrees), those of you who believe and have been granted knowledge. ${ }^{42}$

Critical thinking is thinking at a higher-level. It is used to clarify and evaluate statements, as well as to highlight distinctions. While thinking facilitates the expression of theories, views, or policies, critical thinking is needed to evaluate them. Critical thinking helps to guard against careless or superficial thinking, such as failing to identify important distinctions. Critical thinking seeks to understand the whole by comprehending its component parts and how they are linked to one another. In this sense, critical thinking is analytical. Critical thinking also needs to identify false dichotomies. It can detect, express, and evaluate assumptions, including unstated assumptions. It can clarify implications, both short and long term, of a given statement, policy, or point of view. Critical thinking can also identify inconsistencies and contradiction. With the help of logical analysis, critical thinking can be employed to reconcile inconsistencies in statements, theories, or policies. Critical thinking can help to develop a consistent position, free of contradictions. It can identify faulty argumentation, such as the setting up of 'straw men' or painting caricatures of competing points of view.

Critical thinking, unlike its uncritical counterpart, insists on evidence before something is accepted as true. Islam does not ask anyone to accept its message without compelling reasons, blindly and uncritically, without reflection. On the contrary, the Qur'ān calls our attention to the many 'signs' (āyat)' of God, both in the book of revelation and in the world of creation. These signs constitute the evidence for knowledge and faith. The Qur'ān asks us to reflect on and think about all of God's signs. The need to rely on evidence also applies in the dealings of human beings with one another. Substantiating claims with reliable evidence helps the cause of justice, giving each his due..$^{43}$ The requirement to confirm statements is a sine qua non in critical thinking. Critical thinking helps to protect against deception, including self-deception. It aims to strengthen the certainty (yaqin) of knowledge.

O ye who believe! If a wicked person comes to you with any news, ascertain the truth, lest ye harm people unwittingly, and afterwards become full of repentance for what ye have done. ${ }^{44}$

This verse, like many others, has both a particular, historical meaning, related to the occasion of its revelation, as well as a universal one, applicable regardless of time 
and place. The occasion of its revelation provided the opportunity to learn wisdom. Once the knowledge is revealed, it can be applied in a universal way to countless similar incidents in future. The verse was revealed to show the Muslims how to deal with a specific issue, that of a baseless allegation, where the reputation of an innocent person was at stake. It advises the Muslims to verify reports, and not to jump to conclusions, driven by a desire of one kind or another, as this can result in injustice and regrets. In other words, the verse advises people to withhold judgment until incontrovertible evidence is available. The verse admonishes the faithful to be careful. When someone makes a claim, one needs to ask: "What evidence is there to substantiate this claim? Why should one accept what is claimed? What assumptions does a given statement make? What implications does a claim have if it is true? What implications does it have if it is false?" A critical approach does not take statements at their face value. It seeks to examine the foundations of statements. One's success $(f a l \bar{a} h)$, in this life and in the hereafter, depends on comprehending the message revealed in the Qur'ān and exemplified in the life of the Prophet Muhammad, pbuh. While humanity is unable to generate knowledge comparable to revealed knowledge, human reason is indispensable in comprehending, disseminating, and utilising this knowledge. Reason is also instrumental in discovering and utilising knowledge derived exclusively from empirical data.

If a person accepts a statement or opinion at face value, without inquiring and ascertaining the grounds for the view expressed, he or she is being uncritical. In popular parlance, we would say that the person is 'gullible'. Accepting statements at face value is not recommended. Should it turn out that the view or opinion expressed is either incorrect or misleading, the person acting on, or affected by bad advice could suffer harmful consequences.

Evaluation of claims can utilise empirical or sense data. In addition to sense perception, Islam recognises another, higher form of perception. This is the perception of the 'heart' ( $f u$ ' $a \bar{d}$ and qalb). The 'heart' includes the intellect ('aql) and intuition (ilhām). While metaphysical reality or, as the Qur'ān puts it, 'the unseen' (al-ghayb) cannot be empirically observed by the senses, it can be intuitively perceived by the 'heart'.

Some commentators suggested that critical thinking manifests itself in the Islamic intellectual tradition in the form of $i j t i h \bar{a} d$. Yet the identification of critical thinking with ijtihād is not entirely justified. While ijtihād and critical thinking are similar, they are nevertheless distinct activities. Ijtihād presuppose the capacity to think, and to do so critically. One who thinks critically, however, is not therefore for that reason participating in ijtiha $\bar{d}$. While not everyone is qualified to perform ijtihād, almost everyone can - and should - develop a good measure of critical thinking skills.

ICR 1.4 Produced and distributed by Pluto Journals ICR.plutojournals.org 


\section{The Role of Critical Thinking in Civilisational Renewal}

Critical thinking is indispensable in advancing tajdìd ([civilisational] renewal) and overcoming taqlìd ([indiscriminate] imitation). Tajdìd and taqlìd are two sides of the same coin. Tajdìd is grounded in a well-known tradition, in which the Prophet, pbuh, said that God will raise for His ummah, at the beginning of each century, a leader (mujaddid) that will rejuvenate religion. ${ }^{45}$ "As a principle, tajdì $d$ has guided the path of many a prominent reformer and mujaddid throughout Islamic history... ${ }^{" 46}$ Renewal and tajdīd "necessitate the reinterpretation of Islamic teachings of relevance to current issues ... vigorously undertaken in the light of the unprecedented conditions of modernity and civilisation of the twenty-first century". ${ }^{47}$ Regeneration and renewal necessarily involve critical thinking and evaluation of the existing status quo and the dynamism it takes to change it for the better. It is helpful to make a distinction between renewal (tajdīd) and reform (ișlāh): "the former is of concern mainly to the inner moral and spiritual transformation of the individual under the influence of a religious leader, whereas the latter contemplates social reform and the external aspects of the religion". ${ }^{48}$ At the same time, tajdid and ișlāh cannot be entirely "separated from one another, just as the inner self and outer conduct of the individual may be said to be necessarily inter-connected" ${ }^{49}$ Tajdìd and ișlāh should each be seen as "a logical extension of the other" ${ }^{50}$ Taqlīd or "indiscriminate imitation" and rigid adherence to a particular school of thought, on the other hand, "is widely held to be the single most damaging cause of the decline of creative thinking among Muslims". ${ }^{51}$ Critical analysis can identify the causes of social decline as well as prescribe remedies for its regeneration, based on knowledge of the teaching of Islam.

Islam's long history has undoubtedly witnessed instances of both rejuvenating tajdid, and of deadening stagnation and taqlid. The weight of unwarranted accretions even managed to declare, at some point, the 'door of creative thinking and ijtihad closed'.52

Critical thinking plays a key role in the mastery, dissemination, and utilisation of knowledge in its various forms. In universities, critical thinking is indispensable in assessing research. In the experimental sciences, the truth or falsity of a hypothesis is established with the help of a controlled experiment. Critical analysis is needed in distinguishing truth from fiction, in the light of available knowledge. Rigorous research methodology enhances the integrity of scientific research.

In business, critical thinking is used to evaluate business plans and company performance. Critical thinking plays a key role in the formulation, implementation, and evaluation of corporate strategies. It is also used in the development and marketing of new products and services, developed in response to changing consumer needs and preferences. Critical thinking can assist companies to become 
more efficient, productive, and profitable. Higher productivity in turn contributes to economic development, social prosperity and a better quality of life.

Critical thinking is indispensable in the administration of justice. Following the due process of law reduces the possibility of a miscarriage of justice. Witnesses, providing evidence for the acquittal or conviction of an accused, are cross-examined. All evidence is evaluated. Spurious evidence, bias, the testimony of unreliable witnesses, or hearsay are identified and rejected. By distinguishing reliable from unreliable evidence, critical thinking can help enhance the integrity of the judicial process, and thus contribute to a more just society.

Critical thinking along with participation in public affairs can improve governance. Citizens can voice their concerns on issues pertaining to the well being of the community. Critical thinking can also assist in formulating, implementing, and identifying alternative ways of addressing pressing issues facing the community. Government policy safeguards and advances the public interest (mașlahah). Competing proposals or alternative policies need to be subjected to a critical analysis. The effects of policies, long term and short term, as well as their costs - social and monetary - need to be ascertained in advance. As policies are implemented, critical assessment can monitor their effectiveness and assist in fine-tuning them as required.

Critical thinking can identify unwarranted accretions to religious beliefs and practice: "The majority of Muslims today are [...] woefully uninformed [...] on the authoritative validity of reason." ${ }^{53}$ Critical analysis can investigate views or practices for their compliance with the teaching of Islam. Evaluation, however, can only take place with reference to a criterion. This criterion is the teaching of Islam, as explained in the Qur'ān and illustrated in the life of the Prophet Muhammad. The Qur'ān refers to itself as precisely such a criterion (furqān). Islam teaches what to accept and what to reject, what is right and true (haqq) and what is wrong (bātil), the difference between knowledge ( $\mathrm{ilm}$ ) and ignorance (jahl), between piety (taqwā) and rebellion (bughā) as well as other knowledge. Islamic critical thinking uses revealed knowledge as the criterion for differentiating right and wrong. Islamic critical thinking thus differs in a fundamental way from 'Western' critical thinking, because the Western worldview in general accords only empirically verifiable knowledge the status of bona fide knowledge.

Critical thinking can enhance moral integrity. Hisbah, or 'commanding what is good and prohibiting what is evil' (al-amr bi 'l-ma 'rüf wa 'l-nahy 'an al-munkar) is integral to the teaching of Islam, something all Muslims are commanded to practise. Says the Qur'ān:

You are the best of peoples, evolved for mankind, enjoining what is right, forbidding what is wrong, and believing in Allah [... ${ }^{54}$ 
Hisbah requires offering sincere advice (nașịhah). Sincere advice may be offered to "anyone, including the 'ulamā' and government leaders". ${ }^{55}$ Critical thinking is indispensable in giving sincere advice or nasiha, as advice can legitimately be offered only after someone is perceived to be in need of such advice. This normally happens when someone observes a departure of a given practice or statement from the Islamic norm. When such a departure is noted, sincere advice or constructive criticism becomes justified. As a result of remedial action, initiated in response to sincere advice, the divergence of a given practice from the prescribed norm, which gave rise to the sincere advice in the first place, would be expected to diminish. The Qur'ān contains much good advice (nașīhah). It identifies people's weaknesses and exhorts them to mend their ways. Being self-critical is a way of applying critical thinking to oneself. Criticism or determining how well a society lives up to the noble ideals of Islam, whether individually and collectively, is indispensable for self-improvement. The expression for 'improvement' (ișläh) occurs frequently in the Qur'ān. Those who mend their ways are spoken of in an approving way.

\section{Causes of the Decline in Critical Thinking}

During "the first three centuries of Islam, known as the era of $i j t i h \bar{a} d[\ldots]$ open enquiry and direct recourse to the sources of the shari ${ }^{-} a h$ was not restricted". ${ }^{56} \mathrm{After}$ the fourteenth century, however, thinking began to decline in the Muslim world. One reason for this was the rise of taqli $d$ or indiscriminate imitation. There were other reasons, however. As a result of "the Mongol invasion and burning of Baghdad, the defeat of the Muslim Arabs in Spain and the continuing crusades, the collapse of the Ottoman caliphate and the ensuing onslaught of European colonialism [...] the sciences fell into a rapid decline [...]. It was argued that orthodoxy was being threatened and that there was a need to restrain thinkers to defend religion." ${ }^{57}$

Intellectual disagreement ( $i k h t i l a \bar{f}$ ) is sometimes confused with disputation. Islam distinguishes two types of disputation (jadal), positive and negative. Disputation in the positive sense is permitted in the Qur'ān. 'Indeed, it is one of the major qur'ānic themes which occurs on no less than twenty-five occasions where the sacred text expresses humanity's inclination, as rational beings, towards argumentation. ${ }^{.58} \mathrm{As}$ criticism can easily be identified with negative disputation (mira'), people worry that whatever critical feedback they might wish to offer might not be appreciated and perceived as purely gratuitous. This may restrain people from offering valuable feedback to those in need of it. Cultural constraints may mean that criticism, if expressed, is muted or low key. While a degree of disagreement (ikhtiläf) is to be expected in an intellectual exchange of ideas, dissent should not be seen as a threat, as long as it is expressed in peaceful, reasonable, and law-abiding ways. When dissenting views remain below the surface, the opportunity to express sincere advice 
(nașìhah) is missed and the community will not be in a position to benefit from it. Lack of criticism may mean that error becomes institutionalised, and even passed on from generation to generation.

Islam guarantees the freedom of expression (hurriyyat al-ra'y). "Individuals can have but little dignity if they are denied the right to give opinions and voice their feelings in matters that concern them." 59 The freedom of expression includes the freedom to express a personal opinion $\left(\mathrm{ra}^{\prime} \mathrm{y}\right)$, as long as such expression does not take the form of blasphemy or sedition (fitnah). ${ }^{60}$ The freedom to express an opinion includes the freedom to express one's views on religion: “The Qur'ān has encouraged rational argumentation in religious matters, and it has consistently recommended investigation and inquiry into almost all aspects of creation." ${ }^{91}$ Yet not all instructors encourage their students to express their views, especially on the subject of religion. This practice hinders the cause of thinking as well as critical thinking. Some teachers justify this habit by saying that religion is a private matter. Others justify their disinclination to allow students to express themselves on religion by saying that students do not have enough knowledge to do so. Yet it is by expressing oneself on a topic that one solidifies one's knowledge of it. Expressing oneself in an informed and articulate way requires thinking as well as critical thinking. Thinking is required to develop and communicate perspectives. Critical thinking enables the anticipation of possible objections to one's views. Thus it helps to formulate statements with greater care and circumspection. Discouraging students from expressing themselves in class, except in a parrot-type fashion, denies them the opportunity to develop not only thinking but also communication skills. Moreover, discouraging students from expressing their views may hinder them in providing sincere advice (nașinhah) to others: "the qur'ānic principle of commanding good and forbidding evil (hisbah) [...] takes for granted the basic freedom of individuals to formulate and express their own opinions". ${ }^{62}$ The advice in the Qur'ān is that everyone should "reflect on the Qur'ān", and that everyone should "command what is good and prohibit what is evil", provided this is attempted from a position of knowledge.

The propensity to discourage the expression of 'personal opinion' by students on the Qur'ān may be due to the fact that the expression of a 'personal opinion' by a lay person has not been adequately differentiated from the expression of a 'personal opinion' by a specialist, a jurist (faqīh) or mujtahid. The expression of a 'personal opinion' by a learned scholar or mujtahid is called ijtiha $\bar{d}$, the process of deriving a ruling $(h u k m)$ of sharì $a h$ in relation to a new problem, for which no clear text is available in the sources. In English it is customary to translate the term ijtihäd as 'personal opinion' or 'personal reasoning'. However, as almost everyone expresses 'personal opinions', or uses 'personal reasoning', it becomes difficult to differentiate the personal opinion of an ordinary person from that of a specialised scholar. The rendering of $i j t i h \bar{a} d$ as 'personal opinion' may give the impression that the expression 
of a "personal opinion", on a subject related to Islam, by a layperson constitutes an ill-advised attempt to do ijtihād. Expressions of 'personal opinions' by students could be perceived as attempts to partake in ijtihād for the same reason. But mere intellectual or 'aqli activity does not necessarily "involve the inference of a $h u k m$ shar ' $l$ from the evidence present in the sources" ${ }^{63}$ Accordingly, an expression of an opinion by a student - for example on a verse of the Qur'ān - may not constitute $i j t i h \bar{a} d$. To avoid mistaking the expression of a "personal opinion" on Islam for an attempt to engage in ijtihād, it is better to render ijtihād in English as "juristic reasoning ${ }^{6}{ }^{64}$ This expression makes it clear that the reasoning in question is that of a competent scholar not a novice. It should be noted in addition, that an expression of an 'opinion' on the Qur'ān is not the same as 'following one's opinion'. Opinions can be expressed - for instance for the purpose of exchanging ideas or comparing notes - without being followed.

The well intentioned but counter-productive habit of some instructors - with notable exceptions - of not encouraging their students to express themselves on the Qur'ān may have been reinforced by a saying ascribed to the Prophet Muhammad: "Whoever says something in interpreting the Qur'ān based on his own opinion should find his place in the Fire." ${ }^{65}$ It appears that "interpreting the Qur'ān based on one's opinion", here means expressing a view on the Qur'ān - or any part of it - in isolation from the widely accepted interpretations. In so far as the intention inherent in this advice is to protect people from straying as a result of adopting views on the Qur'ān independently of established interpretations, discouraging people from forming and expressing their views on the Qur'ān is laudable. Expressing one's point of view, however, requires formulating one. Formulating a point of view, as well as expressing it, in turn requires the application of intellect (' $a q l$ ). Apart from whatever salutary effects it might have, it is hard to see how this advice - no matter how well intentioned - would not also have the unwelcome effect of discouraging Muslim students from pondering (thinking about) the verses of the Qur'ān. The absence of an opportunity to express one's thoughts on a particular subject reduces one's incentive to think about that subject in the first place. One of the great attractions of learning is the ability to share knowledge with others. When the opportunity to do this through exchange of ideas and presentations - which require the expression of one's views - is missing the incentive for participating in the learning process diminishes considerably.

The advice that one should refrain from expressing one's opinion in matters of religion - directed to students in particular - is customarily justified by saying that students do not have enough knowledge to express any views on the Qur'ān, which is the prerogative of experts. One must have knowledge to begin with, such as knowledge of Arabic, in order to comprehend the revealed knowledge recorded in the Qur'ān. Students are accordingly advised to follow time-honoured 
interpretations. Yet the Qur'ān states that it is God who teaches and explains the Qur'ān. ${ }^{66}$ The need to follow generally accepted interpretations has made it hard for students to access the Qur'ān directly. This means a missed opportunity to approach the Qur'ān with a perspective unaffected by prior exposure to human interpretations of the divine text. Students in effect get to read the Qur'ān through someone else's eyes. Yet the Qur'ān is a universal document with a message for all humankind. In so far as each generation faces new challenges, the Qur'ān needs to be read by each generation in its own historical context. Interpretations that have been produced in historical settings long gone may be of limited use in the contemporary context with its unique features, such as globalisation. The danger in accessing the Qur'ān through the eyes of the interpreters of old is that the reader may miss a substantial part of the teaching of the Qur'ān, as former interpreters would have highlighted themes in the Qur'ān that had particular relevance to their own time and place, as well as to the specific predicaments they were confronted with. ${ }^{67}$

The Qur'ān does not expressly forbid or even discourage forming or following 'opinion'. It advises against forming and following desires, either other people's or one's own. The expression "Do not follow your opinion" does not occur in the Qur'ān. Instead we encounter - in no fewer than 18 verses - censure of following one's own or other people's desires $(a h w \bar{a}){ }^{68}$

They reject (the warning) and follow their (own) lusts but every matter has its appointed time. ${ }^{69}$

Then We put thee on the (right) way on religion: so follow thou that (way), and follow not the desires of those who know not. ${ }^{70}$

The word $a h w \bar{a}$ means desires. ${ }^{71}$ 'Opinion', no matter how ill conceived, is formed in and by the 'heart', the mind ( 'aql) and intuition (ilhām). 'Desires' (ahwā), on the other hand, the desires for food, sex, wealth, power, and fame, are formed in and by the less rational parts of the human soul. It is generally acknowledged that desires are significantly more compelling than opinions. 'Opinions' tend to have limited impact on people, unless they are accompanied by the prospect of a fulfilment of a desire. This is part of human nature. In order to be "on the safe side" a person who has been advised to refrain from expressing an 'opinion' of his own, might also refrain from using his intellect ( $a q l$ ). This line of reasoning could hardly fail to have the effect of discouraging intellectual activity. The advice not to follow one's 'opinion' places the mind, indispensable in arriving at any kind of opinion, in an unfavourable light. Such advice cannot but have the effect of making people feel as if the use of one's intellect was somehow dangerous. The opposite may be said of desires. It may appear to the unsuspecting that it might be alright to indulge in 
desires, as long as such indulgence does not take the form of expressing his or her 'opinions'.

Having been advised against following their 'opinion', Muslim students tend to refrain from expressing their views on the Qur'ān, fearing that this could amount to interpreting the Qur'ān 'based on their opinion'. The Qur'ān thus comes to be treated as a text to which only a few are permitted direct access, rather than as a "message to all the worlds", as the Qur'ān declares repeatedly. Yet the Qur'ān teaches that no one can bear another person's burdens. Everyone is individually responsible for his or her deeds. Accordingly, "People are [...] advised to use their own judgment and distinguish between guidance and misguidance in the light of reason. This is because they themselves, and not their self-styled leaders, would ultimately be held responsible." 72

The fact that teachers at times lack the very skills they are expected to teach to their protégés has not helped matters. In a number of learning environments, students are spoon-fed. Some function poorly without constant supervision. Studies are largely exam oriented. An over-reliance on monologue and monotone methodology of teaching allows little time for debating, presentations and discussions. Rote learning (repetition) forces students to memorise material verbatim, sometimes without comprehending, what they have memorised. Mechanical learning inhibits the active mind. Bright students experience discomfort in such an environment. Their interest in learning diminishes, research funds remain underutilised, and the potential of students remains largely underdeveloped. Graduates learn few higher-order thinking skills and remain dependent on others even during adult life, when a degree of self-reliance could justifiably be expected of them. "The business sector is complaining at the quality of graduates they receive from the universities who sometimes could not even comprehend the manual of an equipment what more the way it works. Employers feel that schools have failed to produce students who are knowledgeable and well-equipped with thinking skills which are very much demanded in most working sectors." $" 73$

\section{Conclusions and Recommendations}

- There is a need to introduce courses in critical thinking skills in institutions of learning where they have not been introduced already, and developed further in institutions that already offer them.

- Critical thinking needs to be emphasised across the curriculum; not only in one subject. It should be made clear to the students that the use of one's mind is neither a sign of impiety, nor does it amount to indulging in 'conjecture'. The use of one's reason is not forbidden. On the contrary, it is recommended. 
- There needs to be tolerance for diversity of views. The expression of diverse views does not necessarily encourage anarchy or legitimise value relativism. The Islamic worldview allows ample room for the expression of diverse ethnic, cultural, and religious perspectives, without disadvantaging anyone in particular. Staff and students need to be encouraged to develop and express helpful points of view without fear of reprisals. There should be a climate of cooperation.

- Students should be encouraged to participate in classroom discussions, debates, and express critical perspectives on issues. There should be plenty of presentations, debates and fora. These events should be followed by question and answer sessions. Visiting speakers should expose students to new approaches of learning. Various debating clubs should be established. Public or private funding should be provided for useful events.

- Rote learning methods need to be enhanced with methods that emphasise analysis, comprehension, and communication. Emphasis should be placed on comprehending text, not just memorising it. More centres of learning, with good facilities, should be established. Libraries should be equipped with computers, internet, videos and other facilities. There should be rooms for discussions.

- Students themselves should be enabled to organise and lead their own activities such as debates and publications.

\section{Notes}

1. M.A. Zaki Badawi, "Islamic Universities in British Universities: Challenges and Prospects", in: Abd. Samat Musa, Hazleena Baharun and Abdul Karim Abdullah [Leslie Terebessy] (eds), Islamic Studies in World Institutions of Higher Learning (Kuala Lumpur: Islamic University College of Malaysia, 2004), 8.

2. Mohammad Hashim Kamali, "Islam, Rationality, and Science”, Islam and Science 1, no. 1 (June 2003), 123.

3. Qur'ān 23:78. See also 16:78; 32:9; 57:23. The Abdullah Yusuf Ali translation is used in all cases, unless otherwise specified.

4. Qur'ān 3:190. See also 45:3-5; 51:20-1.

5. Ibid. $21: 10$.

6. Ibid. 38:29.

7. Ibid. 47:24. See also $12: 111$.

8. Muhammad Asad, Islam at the Crossroads (Kuala Lumpur: The Other Press, 1982), 93-4.

9. Ibid., 94.

10. Ibid., 92-3.

11. Ibid., 95 .

12. Mohammad Hashim Kamali, Freedom of Expression in Islam (Kuala Lumpur: Ilmiah Publishers, 1998), 14.

13. Qur'ān 8:22. See also 7:179; 10:100; 25:43.

14. Ibid. $44: 2 ; 2: 2$.

15. Qur'ān 2:255.

ICR 1.4 Produced and distributed by Pluto Journals ICR.plutojournals.org 
16. Ibid. 16:125, Mohammed Marmaduke Pickthall translation.

17. Kamali, Freedom, 65.

18. Qur'ān 54:17, 22, 32, 40.

19. M. Hakan Yavuz, Islamic Political Identity in Turkey (New York: Oxford University Press, 2003).

20. Ibid., 194.

21. Peter Mandaville, "Islamic Education in Britain: Approaches to Religious Knowledge in a Pluralistic Society", in: Robert W. Hefner and Muhammad Qasim Zaman (eds), Schooling Islam: The Culture and Politics of Modern Muslim Education (Princeton, NJ: Princeton University Press, 2007), 224-41.

22. Ibid., 234.

23. Ibid., 236.

24. Yoginder Sikand, "Madrasa Reform in India," available online at http://madrasareforms.blogspot. com/2008/02/interview-arshad-amanullah.html (accessed on 15 February 2010).

25. Anouar Majid, Call for Heresy: Why Dissent is Vital to Islam and America (Minneapolis, MN: University of Minnesota Press, 2007).

26. Ibid., $x$.

27. Ibid., 13.

28. Ibid., 1.

29. "A Celebration of Heresy: Critical Thinking for Islamic Reform", held in Atlanta GA, United States, 28-30 March 2008, available online at http://www.payvand.com/news/08/mar/1107.html (accessed on 12 November 2008), 1.

30. Ibid.

31. Ibid.

32. Khurshid Ahmad, "The Challenge of Global Capitalism: An Islamic Perspective", in: John H. Dunning (ed.), Making Globalization Good: The Moral Challenges of Global Capitalism (Oxford: Oxford University Press, 2004), 181-209.

33. Ibid., 190.

34. Azyumardi Azra, "Education and Literacy in the Muslim World: Paths to the Future", paper presented at the International Forum on 'The Makkah Declaration: Implementing Economic Agenda of the Muslim World', organised by the Institute of Strategic and International Studies (ISIS), Kuala Lumpur, 1-3 September 2007, available online at www.isis.org.my/html/events/event_makkahdeclaration.htm (accessed on 13 July 2009), 4-5.

35. Ibid.

36. Ibid.

37. Suriyakhatun Osman, "Module 9 Critical Thinking", available online at http://holisticleaders.com/ Programs/Critical\%20Thinking.html (accessed on 18 July 2009).

38. Ibid.

39. Ibid.

40. Ibid.

41. Kamali, "Islam, Rationality, and Science", 124.

42. Qur'ān 58:11.

43. Cf. ibid. 45:22.

44. Qur'ān 49:6. See also 60:10.

45. Mohammad Hashim Kamali, Civilisational Renewal (second revised ed., Arah Publications, 2009), 51.

46. Ibid.

47. Ibid., 71.

48. Ibid., 53.

49. Ibid.

50. Ibid., 54.

51. Mohammad Hashim Kamali, "Reading the Signs: A Qur'ānic Perspective on Thinking", Islam and Science 4, no. 2 (Winter 2006), 157.

52. Ibid., 58. 
53. Ibid., 162.

54. Qur'ān 3:110.

55. Kamali, Freedom, 26.

56. Mohammad Hashim Kamali, An Introduction to Shari'ah (Kuala Lumpur: Ilmiah Publishers, 2006), 163.

57. Kamali, "Reading the Signs", 158.

58. Kamali, Freedom, 65.

59. Ibid., 11.

60. Ibid., 62 .

61. Ibid., 15-16.

62. Ibid., 26.

63. Mohammad Hashim Kamali, Principles of Islamic Jurisprudence (Kuala Lumpur: Ilmiah Publishers, 1991), 368.

64. Kamali, Freedom, 2.

65. al-Tirmidhī, hadìth no. 4023, in: Khalid Baig, "Relating to the Qur'an", Albalagh, available online at http://www.albalagh.net/food for thought/quran4.shtml (accessed on 19 February 2010); see also Abū Muhammad b. 'Īsā al-Tirmidhī, Al-Jāmi 'al-șah̄īh, "Kitāb tafsīr al-qur'ān" (Beirut: Dār al-Kutub al- 'Ilmiyyah, 2nd ed. 1427 AH/2006), 685, ahädìth no. 2950, 2951, 2952. Neither al-Bukhārī nor Muslim recorded these Traditions. I would like to thank my colleague at IAIS, Fariz Zainal, for helping me to locate these references.

66. Qur'ān 55:2; 75:17, 19.

67. According to Khaled Abou El Fadl, a number of Muslims treat the views of selected jurists as "immutable and beyond questioning"; see his The Great Theft: Wrestling Islam from the Extremists (San Francisco: HarperSanFrancisco, 2005), 152.

68. Qur'ān 2:120, 145; 5:48, 77; 6:56, 119, 150; 13:37; 23:71;25:43; 28:50; 30:29; 42:15; 45:18; 47:14, 16; $54: 3$. Once again, I would like to thank my colleague, Fariz Zainal, for helping me to locate these references.

69. Qur'an 54:3.

70. Qur'an 45:18.

71. The Arabic word hawā in fact means 'love', 'affection', 'passion', 'inclination', 'liking', 'bent', 'wish', 'desire', 'longing', 'craving', 'fancy', 'whim', 'caprice', and 'pleasure'. 'Opinion' simply does not appear among the connotations of hawā; see Hans Wehr, A Dictionary of Modern Written Arabic, ed. J. Milton Cowan (London: MacDonald \& Evans Ltd, 1974), 1040.

72. Kamali, "Islam, Rationality, and Science", 128.

73. Rosnani Hashim and Suhaila Hussein, The Teaching of Thinking in Malaysia (Research Centre, International Islamic University Malaysia, 2003), 2. 